\title{
GREEN GROWTH AND USE OF EU STRUCTURAL FUNDS IN BALTIC STATES, CZECH REPUBLIC AND SLOVAKIA
}

\author{
Dalia Štreimikienè, Asta Mikalauskienè
}

\section{Introduction}

Green growth is resource-efficient, cleaner economic growth and more resilient without slowing it. Green growth policies pursue a variety of goals, they are best served by a combination of instruments. There are many questionable assumptions in the discussion of economic growth. One of them is the idea that governments are able to achieve sustained high growth. Another one is the believe that the solution to pressing financial and social problems centers on higher growth. The solving of such problems is about radical growth in environmental and resource-saving technologies. It is also about radical "de-growth" in products and processes that undermine longterm living and production conditions (Janicle, 2012). Green growth not only affects the quality of growth, but overall production. In this case, growth results from the investment in the upgrading of the entire production system to environmental and resource-saving processes and products. A prototype of this phenomenon is the climate-friendly "low-carbon economy." In this broader sense, there is also discussion of sustainable "green economy," referring to a comprehensive business innovation process. Green growth is EU policy priority. Green growth of EU member states can provide for cohesion and harmonious development of EU member states.

More than one third of the EU's total budget is spent on so-called Cohesion Policy via the structural funds. Its main purpose is to promote the overall harmonious development of the $E U$, to reduce disparities between the levels of development, and to strengthen its economic and social cohesion. However the results of studies completed for assessment of use of EU structural Funds to ensure cohesion are contradictory (Mohl \& Hagen, 2009). Generally, the literature review does not lead to clear-cut results. Some authors do empirical evidence for a positive impact of European structural funds. The conclusions are based on different sample sizes and different EU member states. Bussoletti and Esposti (2004) use an EU-15 sample, whereas smaller samples are used by Cappelen, Castellacci, Fagerberg and Verspagen (2003) (EU-9) or Bouvet (2005) (EU-8). Some studies even concentrate on single country studies such as Eggert, von Ehrlich, Fenge and Konig (2007) (Germany) or Antunes and Soukiazis (2005) (Portugal). Furthermore, some authors do not find any statistically significant impact of structural funds on the regional growth rates (Garcia-Mila, \& McGuire, 2001; Dall'erba, \& Le Gallo, 2008). Moreover, in some cases the findings are conditioned on certain aspects. Rodriguez-Pose and Fratesi (2004) conclude that only structural fund expenditures for education and investment have a positive impact in the medium run, whereas expenditures for agriculture do not. Ederveen, Gorter, de Mooij and Nahuis (2002) condition the key results on the assumptions of the convergence model. Assuming that all regions finally catch up to the same level, they find positive evidence. By contrast, assuming that the convergence process is limited to convergence within countries, they do not find a positive impact. Finally, Puigcerver-Penalver (2004) finds that e structural funds to have a positive impact on economic growth.

The aim of this paper is to review and compare achievements of Baltic States, Czech Republic and Slovakia in green growth and use of EU Structural Funds for green growth.

Seeking to achieve this aim the main tasks are:

- to review literature and policy documents on green growth and it's benefits;

- to analyse and compare green growth achievements of Baltic States and Czech Republic and Slovakia in green growth; 
- to analyse and compare use of EU structural Funds for green growth priorities in Baltic States and Czech Republic and Slovakia;

- to develop policy recommendations based on the main findings of analysis conducted.

The methods applied: comparative analysis, graphical analysis, systematization and generalization.

\section{Green Growth}

Over recent years the concept of green growth has burst onto the international policy scene. A term rarely heard before 2008 , it now occupies a prominent position in the policy discourse of international economic and development institutions (Jacobs, 2012). The World Bank, along with five other multilateral development banks, has committed itself to this goal (World Bank, 2012a; 2012b). The OECD has adopted a 'green growth strategy' of research and publications (OECD, 2012). A new international body, the Global Green Growth Institute, supported by a number of governments, has been created to advise countries on its implementation (GGGI, 2012). Using its own preferred label of 'the green economy', the United Nations Environment Programme has published a 600-page report (UNEP, 2011). These four institutions have jointly established a 'Green Growth Knowledge Platform' to provide a locus for research and knowledge about the field (World Bank, 2012c). A number of high level meetings and networks have been established (Global Green Growth Forum, 2012; Green Growth Leaders, 2012). Several countries have adopted green growth as an explicit policy objective (OECD, 2012a), while at the G20 Summits in France and Mexico in 2011 and 2012, the largest economies in the world committed themselves to its promotion (Government of France, 2011; Government of Mexico, 2012). The 'green economy' was a major focus of the 'Rio+20' United Nations Summit in June 2012 (UNCSD, 2012).

The concept of economic growth which also meets environmental objectives is not new. Indeed it lay at the heart of the discourse of 'sustainable development', first popularised by the Brundtland Report (World Commission on Environment and Development, 1987) and subsequently institutionalised by the Rio 'Earth Summit' in 1992 (Dresner, 2008). Sustainable development remains the core principle of international environmental policymaking, and of national environmental planning in many countries. Indeed, the official institutions now promoting green growth insist that it is not a substitute for sustainable development but a way of achieving it (OECD, 2011; UNEP, 2011; World Bank, 2012b). Inherent in the "growth" part of "green growth" is a focus on the relatively long term. And the usual starting point for discussions of long-term development policies is the notion of sustainability (Heal, 2012). In what has deservedly become canonical text, the Brundtland Report (World Commission on Environment and Development, 1987) defined sustainable development as "development that meets the needs of the present without compromising the ability of future generations to meet their own needs." Many subsequent discussions of sustainability refer to its economic, social, and environmental pillars.

For economists, a natural way to sharpen the notion of sustainability is to consider the various stocks a nation or group of nations holds at any particular time. These would include various types of renewable and nonrenewable natural resources, fixed capital, knowledge, human health, human capital, and environmental quality. What Heal (2012) calls weak sustainability would then be defined as the requirement that the stocks we pass to future generations be at least as capable of providing them with good living standards as the stocks we inherited. This doesn't mean that none of our stocks can ever be reduced, just that the overall value of the whole portfolio cannot be decreased (Schmalensee, 2012). Heal (2012) notes, for instance, that both Botswana and Namibia are depleting their stocks of natural capital, but Botswana may be on a sustainable development path because it is building up stocks of human and fixed capital, while Namibia is not doing so. He argues that Saudi Arabia, which is mainly using non-renewable oil resources to support consumption rather than any sort of investment, is "the ultimate country example of unsustainability." Similarly, it is hard to see what assets are being built up to offset the global declines in fish stocks and underground aquifers or the increases in greenhouse gas concentrations.

While these examples are fairly clear, Heal (2012) and Reilly (2012) show that assessing the sustainability of a nation's development path encounters some difficult, longstanding conceptual and measurement issues. All 
economists would agree that GDP growth is not an adequate measure of progress: a nation that sells more of its oil every year to finance increasing consumption is getting poorer, not richer. Selling the family silver to pay the rent does not increase properly measured income, even if it permits a move to a better apartment. Similarly, the uncertain future costs of climate change must be offset against the current benefits of fossil fuel use.

The U.S. Bureau of Economic Analysis has developed a system of Integrated Environmental and Economic Satellite Accounts to address these issues, and the World Bank has developed a conceptual frame-work and data to measure Adjusted Net Savings (Heal, 2012). But serious problems remain. The valuation of such assets as air quality and forested public lands is difficult conceptually.

Hallegatte et al. (2011) assert that Green growth is about making growth processes resource-efficient, cleaner and more resilient without necessarily slowing them. This phrase has no obvious content, since few would intentionally slow growth processes unless doing so had other benefits. Whatever it is intended to mean, the discussion they subsequently present makes clear these authors' view that taking the steps they propose will more likely speed up growth than slow it down. In both these definitions, the "social pillar" of sustainable development is completely absent. In contrast, it plays the central role in the World Bank's push for "inclusive growth," growth that is "broad-based across sectors and inclusive of the large part of the country's labor force" (lanchovichina \& Lundstrom, 2009). Green growth would thus appear to be a "subset" of sustainable development in the sense that only a subset of the capital stocks relevant to meeting the needs of future generations is explicitly considered.

Hallegatte et al. (2011) defend this approach by arguing that social improvements follow more or less automatically from economic growth.

Green growth (GG) and green economy (GE) have been subject to various definitions but those currently being used by international organisations have a lot in common. Green growth seeks to fuse sustainable development's economic and environmental pillars into a single intellectual and policy planning process, thereby recasting the very essence of the development model so that it is capable of producing strong and sustainable growth simultaneously (Samans, 2013). It aims to foster economic growth and development, while ensuring that natural assets are used sustainably, and continue to provide the resources and environmental services on which the growth and well-being rely (OECD, 2011). It is growth that is efficient in its use of natural resources, clean in that it minimises pollution and environmental impacts and resilient in that it accounts for natural hazards (World Bank, 2012). Green economy aims for improved human well-being and social equity, while significantly reducing environmental risks and ecological scarcities (UNEP, 2011). The concept of green economy rests on the economy, the environment and the social pillars of sustainable development. A broader concept of 'inclusive' green growth or sustainable development incorporates fully the social sustainability aspects, in particular enhancing human development and the conditions for the poor and vulnerable (Green Growth Knowledge Platform, 2013).

Greening growth and moving towards a greener economy is complex and multidimensional. It entails (i) pricing externalities and valuing natural assets for the long-run services they provide and pricing externalities; (ii) innovation as a means of breaking with unsustainable growth paths; (iii) the creation and dissemination of new, more environmentally sustainable technologies, goods, and services; and (iv) sectoral shifts and changes in comparative advantage that inevitably imply winners and losers. If GG/GE is to help move countries towards more sustainable development, the social consequences and local contexts of the transition to a greener economy must be central to managing change (Green Growth Knowledge Platform, 2013). GG/GE policies need solid, evidence-based foundations. Assessing and communicating the need for policies and whether they achieve their stated goals requires proper monitoring of the underlying developments, progress, and potential opportunities and risks. GG/GE indicators can serve to improve the level of debate on GG/GE and inform the wider public.

At the 2012 UN Conference on Sustainable Development ("Rio+20"), the Heads of State and Government and high-level representatives recognized the indicators as a necessary means to assess progress towards the achievement of 


\section{Ekonomie}

the sustainable development goals, while taking into account different national circumstances, capacities, and levels of development (Green Growth Knowledge Platform, 2013). Green economy has been proposed as a means for catalysing renewed national policy development and international cooperation and support for sustainable development. And the relevant bodies of the UN system were requested to support collecting and compiling integrated and scientifically based information from national sources (UN, 2012).
Measuring progress on a complex and multidimensional change and identifying relevant indicators are challenging tasks. No agreement exists yet on an analytical framework or a set of indicators to monitor GG/GE. Data for natural capital is notoriously poor and efforts are needed to both collect and harmonise it. Different institutions are relying on different indicators. Different national circumstances, capacities and levels of development add to the complexity of a common approach on indicators. And no single indicator will suffice to capture

\section{Tab. 1: Green growth indicators}

\begin{tabular}{|c|c|}
\hline Green growth performance indicators & Units of measurement \\
\hline \multicolumn{2}{|c|}{ Macroeconomic indicators } \\
\hline Energy intensity & $\mathrm{kgoe} / €$ \\
\hline Carbon intensity & $\mathrm{kg} / €$ \\
\hline Resource intensity (reciprocal of resource productivity) & $\mathrm{kg} / €$ \\
\hline Waste intensity & $\mathrm{kg} / €$ \\
\hline Energy balance of trade & $\%$ GDP \\
\hline Energy weight in HICP & $\%$ \\
\hline Difference between energy price change and inflation & $\%$ \\
\hline Ratio of environmental taxes to labour taxes & ratio \\
\hline Ratio of environmental taxes to total taxes & ratio \\
\hline \multicolumn{2}{|c|}{ Sectoral indicators } \\
\hline Industry energy intensity & kgoe /€ \\
\hline Share of energy-intensive industries in the economy & $\%$ GDP \\
\hline Electricity prices for medium-sized industrial users ${ }^{\star *}$ & $€ / \mathrm{kWh}$ \\
\hline Gas prices for medium-sized industrial users ${ }^{* * *}$ & $€ / \mathrm{kWh}$ \\
\hline Public R\&D for energy & $\%$ GDP \\
\hline Public R\&D for the environment & $\%$ GDP \\
\hline Recycling rate of municipal waste & ratio \\
\hline Share of GHG emissions covered by ETS* & $\%$ \\
\hline Transport energy intensity & kgoe /€ \\
\hline Transport carbon intensity & $\mathrm{kg} / €$ \\
\hline \multicolumn{2}{|c|}{ Security of energy supply } \\
\hline Energy import dependency & $\%$ \\
\hline Diversification of oil import sources & $\mathrm{HHI}$ \\
\hline Diversification of energy mix & $\mathrm{HHI}$ \\
\hline Renewable energy share of energy mix & $\%$ \\
\hline
\end{tabular}


the many dimensions on which progress is needed. Yet, from a communication and policy action viewpoint, too many indicators can be confusing. Thus, further efforts to converge on an internationally agreed set of indicators are necessary.

Europe 2020 is the EU's growth strategy for the coming decade. In a changing world, we want the EU to become a smart, sustainable and inclusive economy. These three mutually reinforcing priorities should help the EU and the Member States deliver high levels of employment, productivity and social cohesion. Concretely, the Union has set five ambitious objectives - on employment, innovation, education, social inclusion and climate/energy - to be reached by 2020 . Each Member State has adopted its own national targets in each of these areas. Concrete actions at EU and national levels underpin the strategy. The 2015 European Semester kicked off in 2014 November with the Annual Growth Survey, which outlined the new Commission's threepillar jobs and growth strategy: boosting investment, accelerating structural reforms and pursuing responsible, growth-friendly fiscal consolidation. In February, the European Commission published a series of country reports in February, analyzing Member States' economic policies. In May 2015, the Commission has published the country-specific recommendations for each Member State, along with an overarching Communication on how to strengthen and sustain the recovery, and how the streamlined European Semester is implemented. There several important indicators of green growth indicated European Commission Reports (Tab. 1).

As one can see from table 1 the green growth performance indicators consists from macroeconomic indicators, sectoral indicators and security of energy supply. All Member States have committed to the Europe 2020 strategy. However, each country has different economic circumstances and translates the overall EU objectives into national targets in its National Reform Programme - a document which presents the country's policies and measures to sustain growth and jobs and to reach the Europe 2020 targets. The National Reform Programme were presented by EU member states in parallel with its Stability/ Convergence Programme, which sets out the country's budgetary plans for the coming three or four years All indicators presented in table 1 were assessed by EU member States in their National Reform programmes. In the next section of paper the dynamics of the main indicators of green growth in Baltic States and Czech Republic and Slovakia will be analysed by applying graphical analysis in order to define the best performing country.

\section{Green Growth Achievements in Baltic States, Czech Republic and Slovakia}

Green growth is the priority of EU cohesion policy and can serve for harmonious development of EU member states. The European Commission encourages more intensive use of the Structural and Cohesion funds EU Structural Funds for green growth. Achievements of Baltic States and Czech Republic and Lithuania in green growth at 2012 in indicators presented in table 1 are summarized in table 2 .

As one can see from information provided in table 2 according macroeconomic indicators related to energy intensity and carbon intensity Latvia and Lithuania are best performing countries however according to industry energy intensity Latvia is the worst performing country having highest energy intensity of industry. Lithuania and Latvia have very low rates of recycling of municipal waste comparing with Czech Republic and Slovakia. Lithuania has lowest energy and carbon intensity of transport and comparable low share of GHG emissions covered by Emission Trading Scheme (ETS). This indicates that country does not put tax burden on many GHG emitting sectors. Regarding security of energy supply Lithuania has the highest energy important dependency. The lowest energy import dependency is in Estonia following by Czech Republic because these countries have abundant local energy resources such as oil shale (Estonia) and coal (Czech Republic). Lithuania has the highest oil import diversification rate and quite low diversification of energy mix. Public R\&D expenditures for energy and environment as the share of GDP are very low in all analysed countries. Estonia has the highest share of public R\&D expenditures for energy and environment but also the highest energy and carbon intensity. Also Estonia distinguishes from other analysed countries with high diversification of energy mix and very high waste intensity as local energy source oil 


\section{Ekonomie}

Tab. 2:

Achievements in green growth in Baltic States,

Czech Republic and Slovakia, 2012

\begin{tabular}{|c|c|c|c|c|c|c|}
\hline $\begin{array}{l}\text { Green growth performance } \\
\text { indicators }\end{array}$ & $\begin{array}{c}\text { Units of mea- } \\
\text { surement }\end{array}$ & Lithuania & Latvia & Estonia & $\begin{array}{c}\text { Czech } \\
\text { Republic }\end{array}$ & Slovakia \\
\hline \multicolumn{7}{|c|}{ Macroeconomic indicators } \\
\hline Energy intensity & $\mathrm{kgoe} / €$ & 0.29 & 0.33 & 0.48 & 0.36 & 0.33 \\
\hline Carbon intensity & $\mathrm{kg} / €$ & 0.89 & 0.79 & 1.50 & 1.09 & 0.84 \\
\hline $\begin{array}{l}\text { Resource intensity (reciprocal } \\
\text { of resource productivity) }\end{array}$ & $\mathrm{kg} / €$ & n.a. & n.a. & n.a. & n.a. & n.a. \\
\hline Waste intensity & $\mathrm{kg} / €$ & 0.23 & 0.17 & 1.72 & 0.19 & 0.17 \\
\hline Energy balance of trade & $\%$ GDP & -7.6 & -6.0 & -1.4 & -4.3 & -6.0 \\
\hline Energy weight in HICP & $\%$ & 16.4 & 15.7 & 14.7 & 14.2 & 18.9 \\
\hline $\begin{array}{l}\text { Difference between energy } \\
\text { price change and inflation }\end{array}$ & $\%$ & 3.8 & 7.3 & 7.2 & 5.0 & 1.8 \\
\hline $\begin{array}{l}\text { Ratio of environmental taxes } \\
\text { to labour taxes }\end{array}$ & Ratio & $13.2 \%$ & $17.7 \%$ & $16.7 \%$ & $13.0 \%$ & $13.7 \%$ \\
\hline $\begin{array}{l}\text { Ratio of environmental taxes } \\
\text { to total taxes }\end{array}$ & Ratio & $6.1 \%$ & $8.7 \%$ & $8.6 \%$ & $6.7 \%$ & $6.2 \%$ \\
\hline \multicolumn{7}{|c|}{ Sectoral indicators } \\
\hline Industry energy intensity & kgoe /€ & 0.18 & 0.39 & 0.23 & 0.21 & 0.30 \\
\hline $\begin{array}{l}\text { Share of energy-intensive } \\
\text { industries in the economy }\end{array}$ & $\%$ GDP & n.a. & n.a. & 12.6 & 14.6 & 15.0 \\
\hline $\begin{array}{l}\text { Electricity prices for medium- } \\
\text { sized industrial users }\end{array}$ & $€ / \mathrm{kWh}$ & 0.11 & 0.11 & 0.08 & 0.10 & 0.13 \\
\hline $\begin{array}{l}\text { Gas prices for medium-sized } \\
\text { industrial users }\end{array}$ & $€ / \mathrm{kWh}$ & 0.05 & 0.04 & 0.04 & 0.03 & 0.04 \\
\hline Public R\&D for energy & $\%$ GDP & 0.01 & 0.01 & 0.02 & 0.02 & 0.00 \\
\hline Public R\&D for the environment & $\%$ GDP & 0.00 & 0.01 & 0.03 & 0.01 & 0.01 \\
\hline $\begin{array}{l}\text { Recycling rate of municipal } \\
\text { waste }\end{array}$ & Ratio & $20.4 \%$ & $15.8 \%$ & $44.2 \%$ & $43.4 \%$ & $22.3 \%$ \\
\hline $\begin{array}{l}\text { Share of GHG emissions } \\
\text { covered by ETS }\end{array}$ & $\%$ & 26.4 & 24.9 & 70.6 & 52.7 & 49.0 \\
\hline Transport energy intensity & kgoe /€ & 0.57 & 0.95 & 0.96 & 0.86 & 0.93 \\
\hline Transport carbon intensity & $\mathrm{kg} / €$ & 1.63 & 2.53 & 2.76 & 2.40 & 2.62 \\
\hline \multicolumn{7}{|c|}{ Security of energy supply } \\
\hline Energy import dependency & $\%$ & 80.3 & 56.4 & 17.1 & 25.2 & 60.0 \\
\hline $\begin{array}{l}\text { Diversification of oil import } \\
\text { sources }\end{array}$ & $\mathrm{HHI}$ & 0.75 & 0.28 & 0.20 & 0.27 & 0.67 \\
\hline Diversification of energy mix & $\mathrm{HHI}$ & 0.29 & 0.30 & 0.45 & 0.27 & 0.22 \\
\hline $\begin{array}{l}\text { Renewable energy share of } \\
\text { energy mix }\end{array}$ & $\%$ & 16.4 & 36.4 & 14.1 & 7.5 & 8.1 \\
\hline
\end{tabular}


shale has very high ash content. All countries have negative energy balance of trade. The (net) energy trade balance is expressed as a percentage of GDP. All other things being equal, the more negative this balance, the higher the likelihood that the current account is vulnerable to energy price shocks, and hence the bigger the contribution of trade in energy products to an external imbalance.
It is important to analyse the trends of the main green growth indicators in Baltic States, Czech Republic and Slovakia in order to assess the impact of use of EU Structural Funds to enhance green growth in these EU member states during 2007-2013.

In figures 1-8 the development of the main indicators of green growth in Baltic States, Czech Republic and Slovakia are presented.

\section{Fig. 1: Energy intensity in Baltic States, Czech Republic and Slovakia}

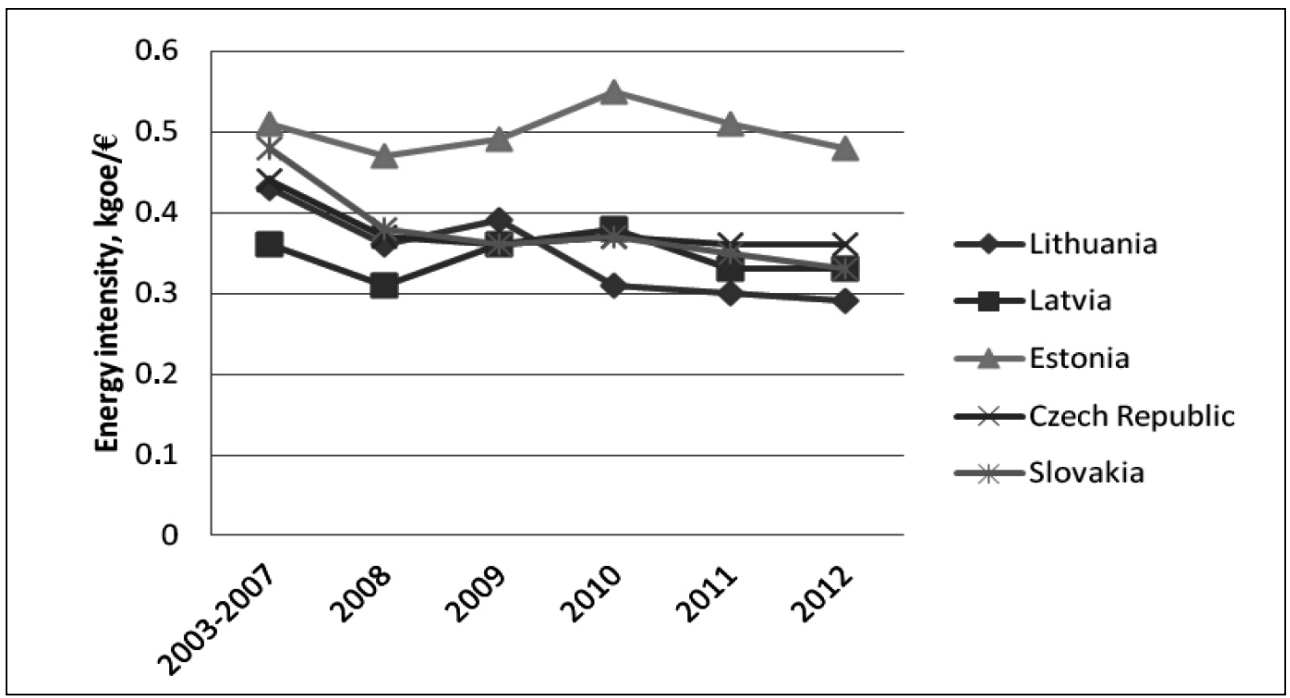

Source: EUROSTAT

The most important indicator of green growth is energy intensity of GDP as this indicator represents also competitiveness, environmental sustainability and energy security issues. Reduce of energy intensity in member states has direct impact on environmental and pollution reduction, climate change mitigation and on increase of competitiveness of economy and security of energy supply. In figure 1 the trends of energy intensity of GDP is compared in Baltic States, Czech Republic and Slovakia. As one can see from figure 1 though all Baltic States and Czech Republic and Slovakia have energy intensity well above EU-28 level the highest energy intensity is in Estonia and the lowest one in Lithuania. Comparing data of year 2004 with energy intensity in 2012 one can notice that energy intensity was decreasing since entering $E U$ in all analysed countries however economic crisis had negative impact and energy intensity stared to increase however in Estonia energy intensity increase can be noticed since 2007 but in 2010 this trend has dramatically changed and energy intensity began to decrease. In other analysed countries the trend of energy intensity decrease can be noticed following the recovery from economic crisis in 2010. In Czech Republic the trends of energy intensity decrease were almost stable during all investigated period.

The $\mathrm{CO}_{2}$ intensity of the economy for the whole EU decreased substantially since 2001 by about $23 \%$. It declined for all Member States. However, similarly to the energy intensity, a trend break occurred around 2008 for a group 


\section{Ekonomie}

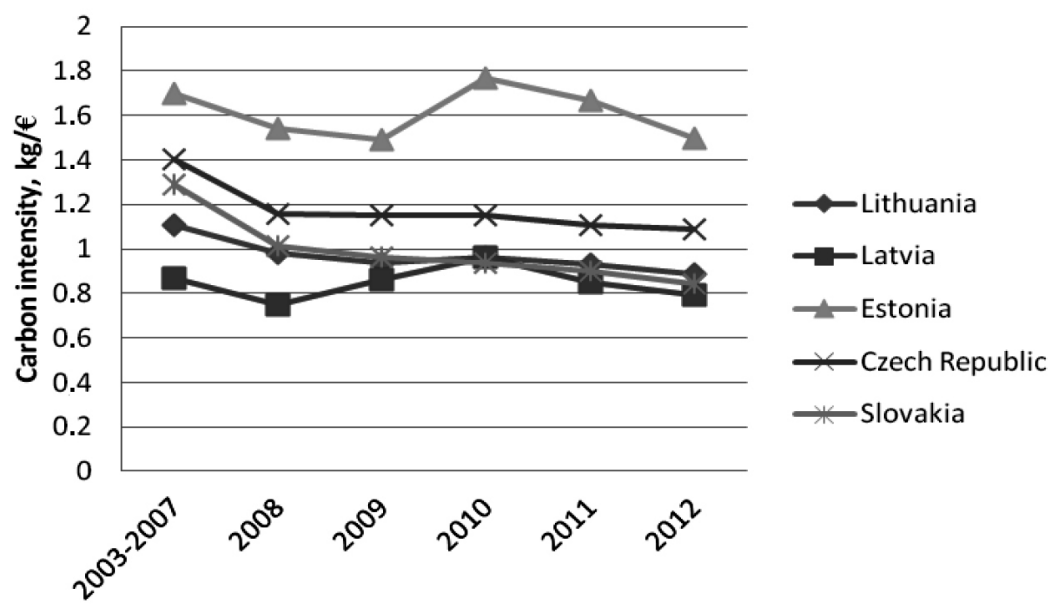

Source: EUROSTAT

of countries when the carbon intensity of these economies started increasing. This is the case for Estonia and Latvia. In Czech Republic carbon intensity was decreasing during all investigated period.

As one can see from the figure 3 the persistently negative energy trade balance can be noticed in all analysed countries. In EU in 2013 negative energy balance in trade amounted to $3.1 \%$ of EU GDP up from $2.1 \%$ of 2009 therefore the negative trends can be noticed in all analysed countries. Especially in Lithuania this trend is very negative since the closure of the second unit at Ignalina NPP in 2009.

As one can see from fig. 4 the ratio of environmental taxes to total taxes was

\section{Fig. 3: Energy balance of trade in Baltic States, Czech Republic and Slovakia}

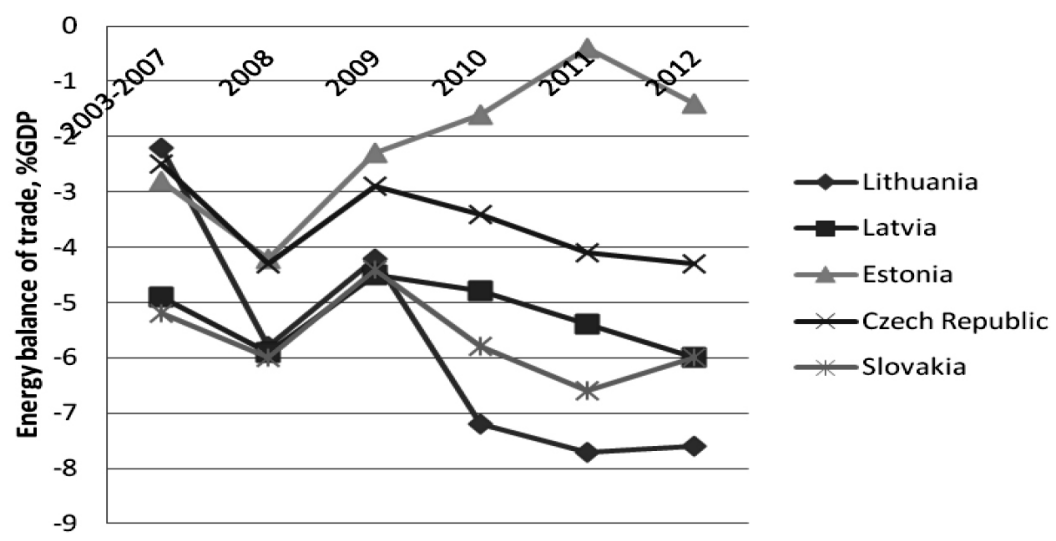




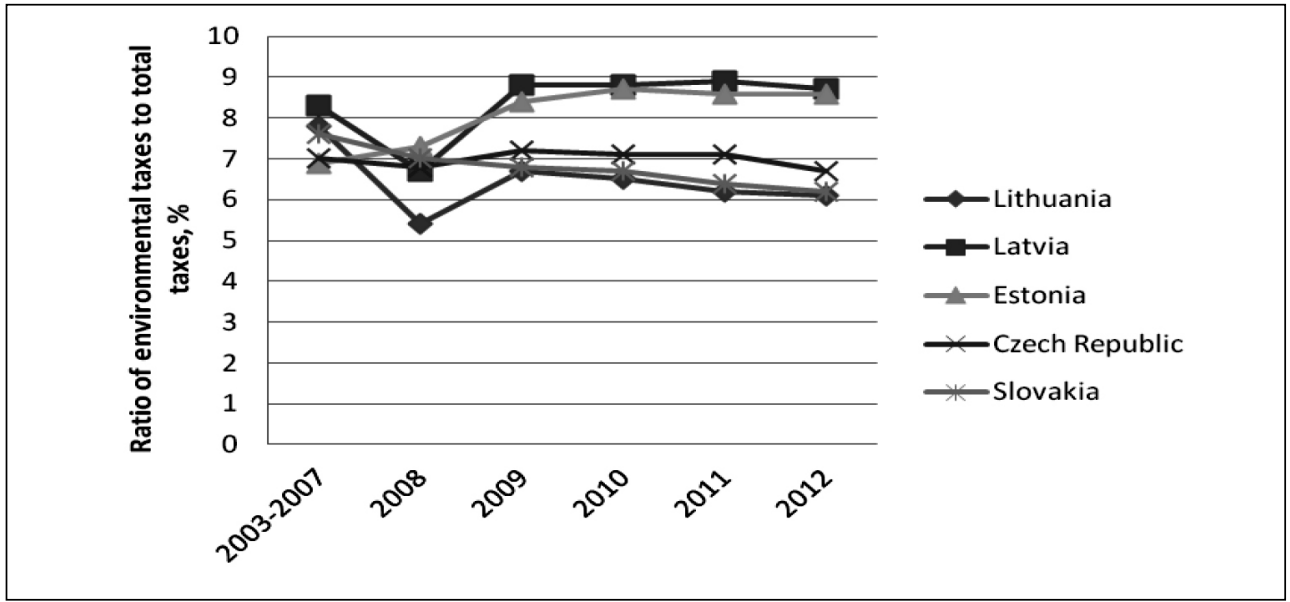

\section{Fig. 5: Public R\&D expenditures for the environment in Baltic States, Czech Republic and Slovakia}

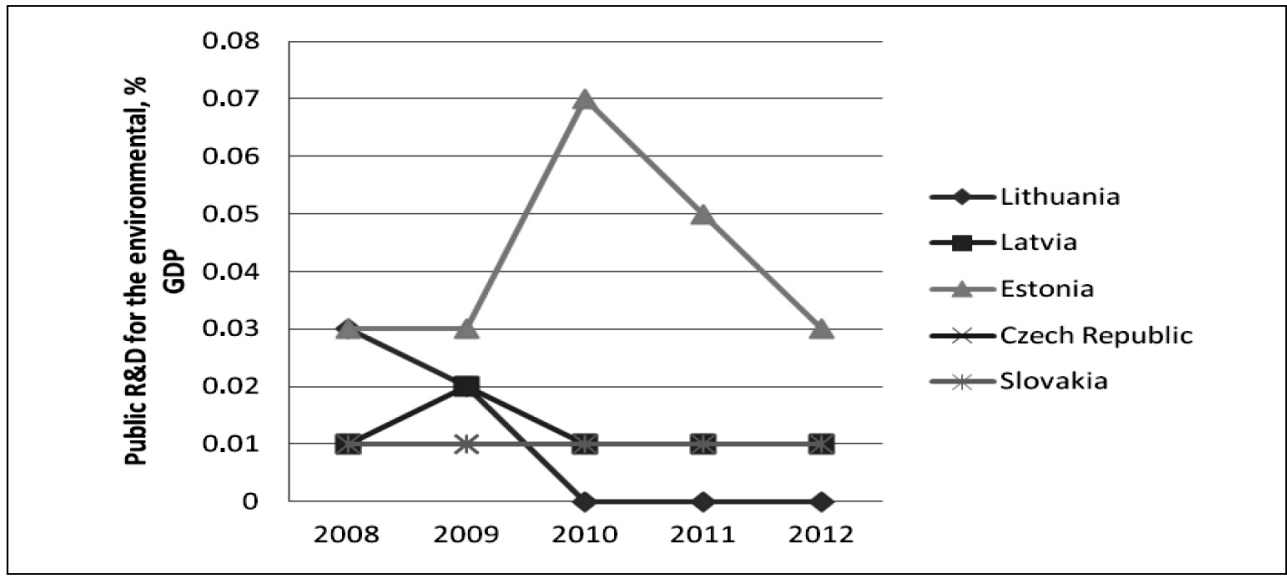

Source: EUROSTAT

increasing since 2009 in all analysed countries however Lithuania and Slovakia remains with the lowest ration of environmental taxes to total taxes between Baltic States, Czech Republic and Slovakia.

As one can see from fig. 5 though Estonia had the highest public R\&D expenditures to environment in 2009 and especially 2010 their began to decline steeply since 2011 and almost reached level of other analysed countries. In Czech Republic public R\&R expenditures remained stable during investigated period.

As one can see from the figure 6 the highest energy dependency rate in 2012 was in Lithuania. This is related with the closure of Ignalina NPP in 2009 and increase of energy import. Before closure of Ignalina NPP Lithuania was net energy exporter. The lowest 


\section{Ekonomie}

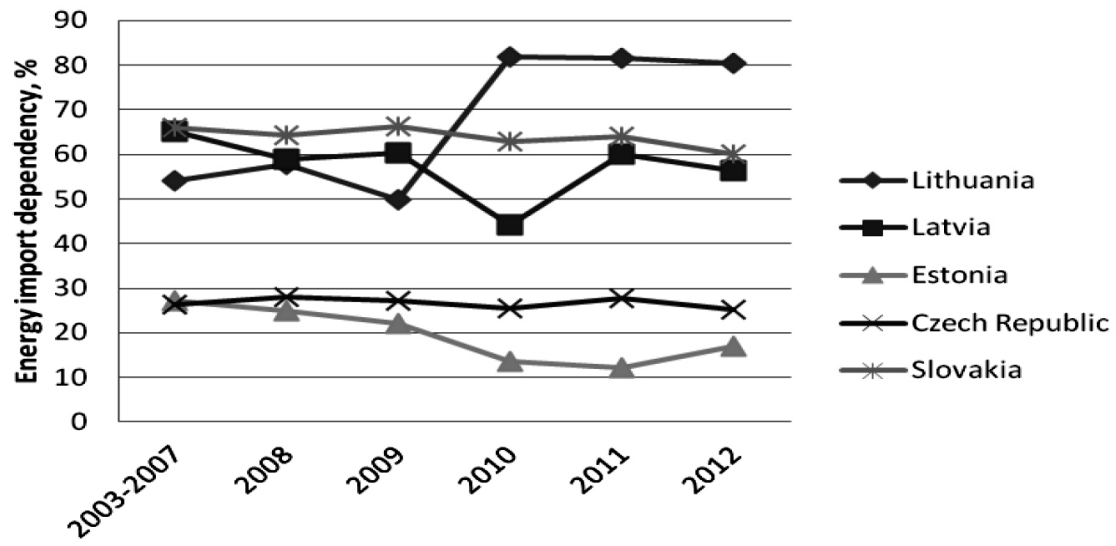

energy import dependency is in Estonia though it has slightly decreased in 2012 comparing with year 2011. Estonia has abundant oil shale resources and has been utilising these resources in energy sector quite intensively however with entrance in force of stringent EU environmental regulations the use of oil shale having high sulphur content is diminishing. Czech Republic also has quite low energy import dependency because of availability local coal resources. Slovakia and Latvia have high energy dependency rate well above EU-28 level however the trends in Latvia and Slovakia are very positive and energy dependency rates

\section{Fig. 7: Diversification of energy mix in Baltic States, Czech Republic and Slovakia}

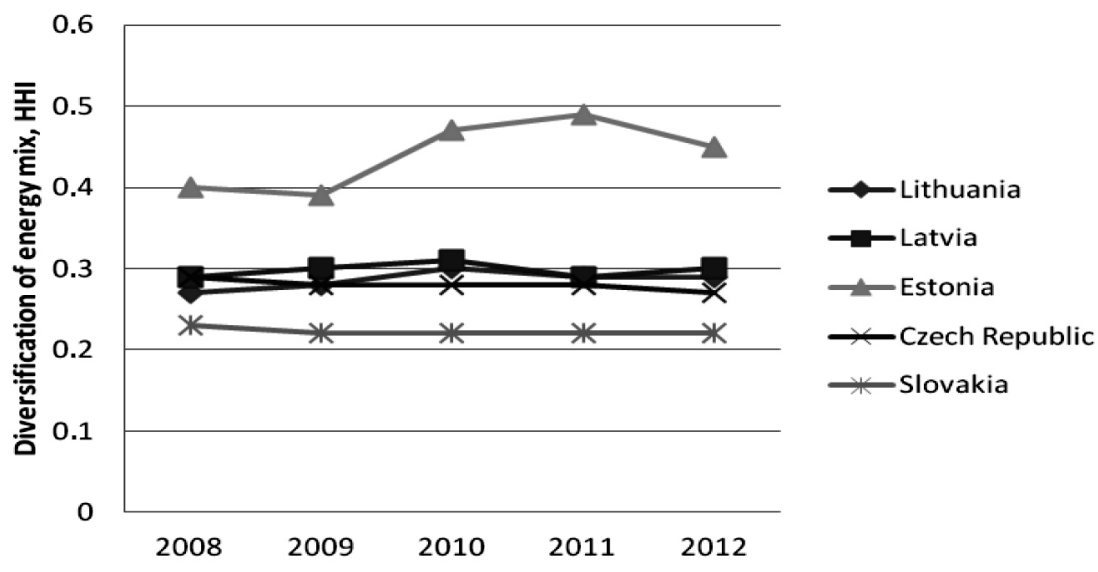




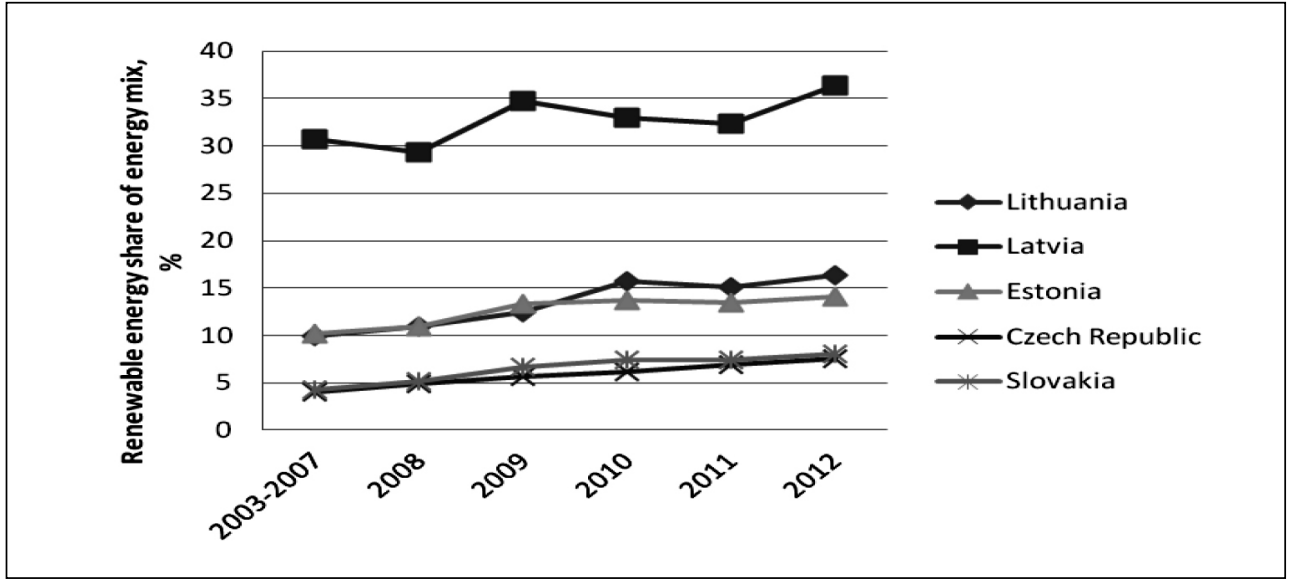

have decreased in these countries from almost $70 \%$ in 2004 to $55-60 \%$ in 2012.

As one can see from the figure 7 Estonia has the highest diversification of energy and since 2009 the trends of energy mix diversification were favourable in Estonia in other analysed countries the situation remained stable during investigated period.

As one can see from the figure 8 Latvia distinguishes with very high share of renewables in final energy which is well above EU-28 level. In Estonia and Lithuania the share of renewables in final energy is also above EU-28 level and has increased significantly since 2004 (by almost $70 \%$ ). The high share of renewables in Latvia is related with the natural conditions and high share of hydro in electricity generation. The lowest share of renewables is in Slovakia and Czech Republic and though since 2004 use of renewables in final energy was increasing in all analysed countries the highest increase was achieved in Estonia. Comparing results achieved by new EU member states with target one can notice that Estonia achieved level above target set for 2020 in 2011.

It is necessary to stress that there is close relationship between green growth indicators as increase in the share of renewables and energy efficiency improvements have direct impact on reduction of energy and carbon intensity of economy and all sectors as well as on decrease of energy import dependency, energy balance of trade and diversification of energy mix. Therefore the priorities of energy policy targeting increase use of renewable energy sources and energy efficiency improvements are important drivers of green growth. In the next section the analysis of use of EU structural funds will be performed seeking to compare countries in terms of means allocated to renewable energy and energy efficiency projects as well according other indicators related with allocations of means from structural funds.

\section{Use of EU Structural Funds in 2007-2013 for Green Growth Priorities in Baltic States, Czech Republic and Slovakia}

European Commission in 2013 developed data on the use of EU structural funds and the implementation of joint projects in the context of the EU countries for 2007-2013. Structural and Cohesion Funds - the EU's main common financial measure to promote its goals and play a central role to play in realising the EU climate change mitigation strategy. The strategy will only succeed if it is implemented through joint and consistent effort at all levels, from the local through regional and national to European, and if it is backed up by adequate financial resources. The funds should be used to help 
the beneficiary member states move towards a sustainable and climate-friendly pattern of development. For this, however, EU cohesion policy aims to be "decarbonised" (Streimikiene \& Balezentiene, 2012). The European Commission encourage more intensive use of the Structural and Cohesion funds to improve energy efficiency in the new Member States, including in the multi-family and social housing sectors. In the table 3 allocation of EU structural funds including the share of structural funds allocated for renewable energy and energy efficiency is presented in Baltic States.

As one can see from information provided in the table 3 the highest amount of EU structural funds per capita was allocated in Estonia and Czech Republic however the highest intensity of financing as the share of GDP was obtained in Lithuania. Comparing with Central and Easter Europe average this financing intensity was high in all Baltic States. The highest payment ratio was obtained in Estonia significantly exceeding CEE average rate. The highest share of allocations for energy efficiency from EU structural funds in 2007-2013 was in Lithuania following Czech Republic however the highest share of allocations for RES in the same period was in Czech Republic and the lowest in Estonia following Lithuania.

Promotion of renewable energy sources (RES) and increase of energy efficiency are priorities of EU energy policy and among green growth indicators the major roles plays energy sector related indicators. In general, the energy sector has received funds and the Cohesion Fund and the ERDF. Some of analyzed countries have supported by RES from both structural funds, but Baltic States for promotion of use of renewable energy sources allocated just means from Cohesion fund. Lithuania and Latvia for financing of RES projects from Cohesion Fund allocated means just for biomass projects and Estonia allocated means for biomass and wind energy products in the 2007-2013 programming period. Estonia has allocated significant amounts of EU structural funds to wind energy projects

Tab. 3: Allocation of EU structural funds in Baltic States in 2007-2013

\begin{tabular}{l|c|c|c|c|c|c|c} 
& Lithuania & Latvia & Estonia & $\begin{array}{c}\text { Czech } \\
\text { Republic }\end{array}$ & Slovakia & CEE total & $\begin{array}{c}\text { CEE } \\
\text { average }\end{array}$ \\
\hline Population (million) & 2.97 & 2.02 & 1.32 & 10.52 & 5.41 & 104.33 & 9.49 \\
\hline Annual GDP (EUR billion) & 34.60 & 23.37 & 18.43 & 149.39 & 72.13 & $1,047.05$ & 95.19 \\
\hline GDP per capita (EUR) & 11,650 & 11,548 & 13,800 & 14,206 & 13,333 & $124,710.07$ & 11,314 \\
\hline EU funds 2007-2013 (EUR billion) & 6.77 & 4.54 & 3.40 & 26.3 & 11.65 & 175.72 & \\
\hline EU funds per capita (EUR) & 2,280 & 2,243 & 2,595 & 2,501 & 2,154 & & 1,830 \\
\hline EU funds per GDP (\%) & 19.6 & 19.4 & 18.5 & 17.6 & 16.2 & & 16.2 \\
\hline $\begin{array}{l}\text { Available budget 2007-2013 } \\
\text { (EUR billion) }\end{array}$ & 6.8 & 4.5 & 3.4 & 26.3 & 11.7 & 174.7 & \\
\hline $\begin{array}{l}\text { Available budget 2007-2013 } \\
\text { per capita (EUR) }\end{array}$ & $2,278.8$ & $2,242.7$ & $2,595.4$ & $2,501.7$ & $2,151.4$ & & $2,102.3$ \\
\hline $\begin{array}{l}\text { Contracted grants 2007-2013 } \\
\text { (EUR billion) }\end{array}$ & 6.7 & 4.4 & 3.3 & 24.2 & 11.4 & 169.4 & \\
\hline Contracting ratio (\%) & 99 & 96 & 96 & 92 & 98 & & 97 \\
\hline Paid grants 2007-2013 (EUR billion) & 5.0 & 3.2 & 2.6 & 16.8 & 6.1 & 105.5 & \\
\hline Payment ratio (\%) & 70 & 70 & 77 & 64 & 53 & & 63 \\
\hline $\begin{array}{l}\text { The share of allocations } \\
\text { for renewables }\end{array}$ & $0.5 \%$ & $0.6 \%$ & $0.3 \%$ & $2.1 \%$ & $0.7 \%$ & & \\
\hline $\begin{array}{l}\text { The share of allocations for energy } \\
\text { efficiency }\end{array}$ & $4.9 \%$ & $2.0 \%$ & $1.9 \%$ & $2.4 \%$ & $1.1 \%$ & & \\
\hline
\end{tabular}


and it would be possible to expect that Estonia has achieved good results in increasing use of renewables especially in electricity generation. Czech Republic was the only country applying the EU Structural Funds for all renewable energy technologies in 2007-2013. Also it was the only country applying more than $2 \%$ of means from Structural Funds to renewabale energy projects.

"National general strategy: the Lithuanian Strategy for the use of European Union Structural Assistance for 2007-2013" is one of the main documents for this programming period in Lithuania. The National General Strategy was supposed to be implemented through four operational programmes (OP): Development of human resources, Economic growth, Cohesion promotion, and Technical assistance. These OP were established on the basis of three main Structural Funds that exist at the EU level: the European Regional Development Funds, the Cohesion Fund and the European Social Funds. The EU funds available for the framework programme are the equivalent of EUR 6.77 billion, with nearly all of these funds being contracted. EU funding played an important role in the Lithuanian economy as it was nearly equal to the annual state budget. In the 2007-2013 financial budgeting period, the majority of the EU funds in Lithuania were spent on economic growth and cohesion promotion OPs. So far the EU funds have been a tool for prosperity which has contributed to achieving faster economic growth, increasing knowledge and competence levels and improving living standards. Additionally, many new workplaces have been created. However there were two major problems related to the 2007-2013 financial budgeting period in Lithuania. First of all, even though there is plenty of data on how the EU funds are structured and implemented there is a lack of summarised data which would indicate how effective these funds were and what additional value was created. For example, recent programmes on energy efficiency improvements in public buildings on average reached only $25 \%$ savings, while the potential to reduce energy consumption by up to $50 \%$ is great. However the analysis of green growth indicators revealed that use of EU Structural Funds especially means from Cohesion fund contributed effectively to increase of energy efficiency and the share of renewables in final energy consumption.

Latvia used financial assistance provided by the EU for economic and social development. In the programming period 2007-2013 the largest financial instruments from which Latvia receives financial assistance were European Regional Development Fund (ERDF), European Social Fund (ESF) and Cohesion Fund (CF) covering three operational programmes (OP) within the National Strategic Reference Framework (NSRF): ESF OP "Human Resources and Employment"; ERDF OP "Entrepreneurship and Innovations" and ERDF and CF joint OP "Infrastructure and Services". The structural assistance available in the programming period 2007-2013 was equivalent to EUR 4.54 billion in Latvia. In the programming period 2007-2013, the largest proportion of EU funds was mainly directed to public education, technological distinction and flexibility of enterprises, as well as development of science and research to facilitate a knowledge-based national economy and strengthen other pre-conditions for sustainable economic development and living conditions in Latvia in general. Although no formal overall evaluation of EU funds implementation in the programming period $2007-2013$ is available yet, initial indications show that in Latvia EU funded investments and implementation of activities have had a positive impact on GDP growth. The increase in energy efficiency and increase in the share of renewables in final energy consumption was achieved because of generous contribution from Cohesion fund.

In Estonia the priorities and goals for structural assistance are set out in the National Strategic Reference Framework 20072013. The framework is carried out through three operational programmes (OP): OP for Human Resource Development; OP for the Development of the Living Environment; OP for the Development of Economic Environment. The structural assistance available for the framework programme is equivalent to EUR 3.4 billion. During the financial period 2007-2013 large investments were made in infrastructure, including roads, water and waste management, schools, hospitals, community centres, R\&D infrastructure, etc. Additionally, EU structural assistance was invested in advancing technology development centres and centres of excellence, and increasing the supply of skilled workers. Structural assistance has been successfully used to reorganise and modernise vocational education to raise its competitiveness. Another achievement is using structural assistance for building innovation systems and for investing 
in R\&D. EU funding was used to finalise the merging of some universities and academies of science and thereby raise the quality of education. Structural assistance has helped to increase the competitiveness of Estonian companies through increased investments in R\&D and exports. Estonia distinguishes with positive trends in many green growth indicators development during 2007-2013 financing period. Especially good achievements can be noticed in increase use of renewables and energy efficiency improvements.

In the Czech Republic the total available budget of Structural Funds and the Cohesion Fund for the period 2007-2013 comprises EUR 26.3 billion, distributed as follows: ERDF - EUR 12.96 billion; CF - EUR 8.82 billion; ESF - EUR 4.52 billion. In the period 20072013 the defined priorities and goals of the Czech Republic are set out in the National Strategic Reference Framework 2007-2013. The Convergence Objective is implemented through eight thematic operational programmes with a total allocation of EUR 21.23 billion and seven regional operational programmes with a total allocated amount of EUR 4.66 billion. The Regional Competitiveness and Employment Objective support regions that do not utilise funds from Convergence objective. In the Czech Republic, the capital city of Prague falls under its scope with two operational programmes and an allocation of EUR 0.42 billion. Individual Operational Programmes show significant differences regarding the amounts of financial support already paid to the beneficiaries. By the end of 2013 the Transport Operational Programme had reached an outstanding payment ratio of $80.6 \%$. Also, the regional Operational Programmes have retained a high payment ratio ranging $66-80.4 \%$ for the entire programme period. The worst payment ratio was shown by the OP Environment at $44 \%$ followed by OP Technical Assistance (45.4\%) and Integrated Operational Programme (47.4\%). The current trend in the Czech Republic is the improvement of effectiveness and transparency of the implementation and audit systems.

Slovakia is implementing EU funds through various programmes. Priorities of the National Strategic Reference Framework (NSRF) are implemented through 11 operational programmes (OP) where there are seven operational programmes under the Convergence objective, three multi- objective operational programmes (for the Convergence objective and the Regional Competitiveness and Employment objective) and one operational programme under the Regional Competitiveness and Employment objective. The beginning of the programming period 2007-2013 was marked by delayed management and control mechanism settings for each operational programme. The low rate of contracting and withdrawal in the initial years for some operational programmes became an urgent issue. Slovak implementing bodies took crucial measures to improve the state of implementation. Several revisions of operational programmes as well as transfer of funds to areas more attractive for the beneficiaries assisted in this improvement.

The conducted analysis revealed that EU funds have been a useful instrument in Baltic States, Czech Republic and Slovakia to reduce the impact of the economic crisis, to slow growth of unemployment and to secure contracts, especially for domestic suppliers. One of the major successes was the partial modernisation of infrastructure in the area of energy sector, education, social services, culture, noncommercial rescue services and other civil infrastructure in towns and municipalities, creating the necessary precondition for increasing benefits to citizens and entrepreneurs from services linked to support.

\section{Conclusions}

Green growth is expected in implementation of Europe 2020 strategy and can provide to harmonized development and cohesion of old and new EU member states. Europe 2020 is the EU's growth based on the growth of smart, sustainable and inclusive economy. These three mutually reinforcing priorities should help the EU and the Member States deliver high levels of employment, productivity and social cohesion. Concretely, the Union has set five ambitious objectives - on employment, innovation, education, social inclusion and climate/energy to be reached by 2020 . These all objectives can be reached by promoting sustainable growth.

There is close relationship between green growth indicators as increase in the share of renewables and energy efficiency improvements have direct impact on reduction of energy a carbon intensity of economy and all sectors as well as on decrease of energy import dependency, energy balance of trade 
and diversification of energy mix. Therefore the priorities of energy policy targeting increase use of renewable energy sources and energy efficiency improvements are important drivers of green growth. In the next section the analysis of use of EU structural funds will be performed seeking to compare countries in terms of means allocated to renewable energy and energy efficiency projects as well according other indicators related with allocations of means from structural funds.

The EU's energy policy key objectives developed since 2007 are energy efficiency and promotion of renewable energy sources. They are directly related with priorities et by Europe 2020 strategy and the Directive 2009/28/ EC providing the legal obligations of the parties, with ambitious goals for the share of RES in final energy consumption. To this end, members of the EU focus great efforts to increase the development of RES and energy efficiency improvements. EU Structural Funds could be used to unlock the large but unused renewable energy potential of the CEE countries. The costs of wind, solar, biomass and geothermal energy have been steadily falling rapidly in recent years, mainly due to the learning effect and economies of scale.

Comparing Baltic States and Czech Republic and Slovakia in terms of progress achieved in green growth several indicators were selected. The trends of security of energy supply, energy efficiency, penetration of renewable energy sources and GHG emissions were compared among five new EU member states.

Estonia distinguishes from analysed countries with good results achieved in achieving several green growth targets, such as high share of renewables in final energy consumption, high security of energy supply (low rate of energy independency), significant decrease in energy intensity and carbon intensity of energy. Czech Republic has achieved good results in increase of security of energy supply and decrease of energy intensity of GDP and carbon intensity of energy. Latvia distinguishes with very high shares of renewables in electricity generation and in final energy consumption however it is more related with favourable climate conditions and well developed hydro power plants.

Estonia is making considerable progress in use of RES and use of EU Structural Funds and local support measures allowed country to achieve the highest increase in the share of renewables in final energy and electricity consumption in 2013. In 2004 the share of renewable in final energy consumption and in electricity consumption in Estonia was lower than in Lithuania but in 2012 Estonia overcome Lithuania almost by $5 \%$.

The EU Structural Funds absorption for promotion of RES promotion in 2007-2013 showed that Estonia was the only country from Baltic States allocating $0.2 \%$ of means from EU Structural Funds for wind energy projects. Lithuania has allocated $0.5 \%$ of means from EU Structural Funds for promotion of biomass projects and together with Latvia which has allocated even $0.6 \%$ of means from EU Structural for biomass projects achieved the best results in utilization of RES in heating and cooling. Czech Republic allocated the highest share of means form EU Structural Funds to enhance green growth. In terms of development of green growth indicators Czech Republic is also among the best performing countries following Estonia.

\section{References}

Antunes, M., \& Soukiazis, E. (2005). Two speed of regional convergence in Portugal and the importance of structural funds on growth. In 4th Annual Meeting of the EEFS, 2005, 19-22 May, Coimbra. Retrieved from: http:// ec.europa.eu/dgs/policy_advisers/docs/13_ paper_rodriguez_pose.pdf.

Bouvet, F. (2005). European Union Regional Policy and Its Effects on Regional Living Standards: A Complete Study. Davis: Department of Economics, University of California. Retrieved from: http://www.eeaesem.com/papers/EEA/2005/948/First_paper_ final_draft_in_growth.pdf.

Bussoletti, S., Esposti, R. (2004). Regional convergence, structural funds and the role of agriculture in the EU. A panel-data approach (Working Paper 220). Universita Politecnica delle Marche, Dipatimento die Economia.

Cappelen, A., Castellacci, F., Fagerberg, J., \& Verspagen, B. (2003). The impact of EU regional support on growth and convergence in the European Union. Journal of Common Market Studies, 41(4), 621-644. doi:10.1111/14685965.00438.

CEE Bankwatch Network. (2014). Channelling EU funds into efficient and renewable energy. Retrieved from: http://www. inforse.org/europe/Structuralfunds/SF_docs/ SF_EUfunds4energy.pdf. 
Dall'erba, S., \& Le Gallo, J. (2008). Regional convergence and the impact of European structural funds 1989-1999: A spatial econometric analysis. Papers in Regional Science, 82(2), 219244. doi:10.1111/j.1435-5957.2008.00184.x.

Dresner, S. (2008). The Principles of Sustainability. London: Earthscan.

Ederveen, S., Gorter, J., De Mooij, R., \& Nahuis, R. (2002). Funds and games. The economics of European cohesion policy (Occasional Paper No. 3). European Network of Economic Policy Research Institutes.

EU Funds in Central and Eastern Europe. Progres report 2007-2013. KPMG in Central and Eastern Europe. Retrieved from: kpmg.com/cee.

European Commission (2015a). Country Report Latvia 2015. Brussels: EC. Retrieved from: http://ec.europa.eu/europe2020/pdf/csr2015/ cr2015_latvia_en.pdf.

European Commission (2015b). Country Report Lithuania 2015. Brussels: EC. Retrieved from: http://ec.europa.eu/europe2020/pdf/csr2015/ cr2015_lithuania_en.pdf.

European Commission (2015c). Country Report Estonia 2015. Brussels: EC. Retrieved from: http://ec.europa.eu/europe2020/pdf/csr2015/ cr2015_estonia_en.pdf.

European Commission (2015d). Country Report Slovakia 2015. Brussels: EC. Retrieved from: http://ec.europa.eu/europe2020/pdf/csr2015/ cr2015_slovakia_en.pdf.

European Commission (2015e). Country Report Czech Republic 2015. Brussels: EC. Retrieved from: http://ec.europa.eu/ europe2020/pdf/csr2015/cr2015_czech_en.pdf.

European Commission. (2015). Excise Duty Tables. Part II - Energy products and Electricity. Brussels: EC. Retrieved from: http://ec.europa. eu/taxation_customs/resources/documents/ taxation/excise_duties/energy_products/rates/ excise_duties-part_ii_energy_products_en.pdf.

Eggert, W., Von Ehrlich, M., Fenge, R., \& Konig, G. (2007). Konvergenz- und Wachstumse efekte der europaischen Regionalpolitik in Deutschland. Perspektiven der Wirtschafts politik, 8(2), 130-146. doi:10.1111/j.14682516.2007.00237.x.

Garcia-Mila, T., \& Mcguire, T. (2001). Do interregional transfers improve the economic performance of poor regions? The case of Spain. International Tax and Public Finance, 8(3), 281-295. doi:10.1023/A:1011264107134.

Global Green Growth Institute. (2012). Retrieved from: http://www.gggi.org/.
Global Green Growth Forum. (2012). Retrieved from: http://www.globalgreengrowthforum.com.

Green Growth Leaders. (2012). Retrieved from: http://greengrowthleaders.org/.

Green Growth Knowledge Platform. (2013). Moving towards a Common Approach on Green Growth Indicators. A Green Growth Knowledge Platform Scoping Paper. Retrieved from: http://www.unep.org/greeneconomy/Portals/88/ documents/partnerships/GGKP\%20Moving $\% 20$ towards $\% 20$ a\%20Common $\% 20$ Approach $\% 20$ on\%20Green\%20Growth\%20Indicators.pdf.

Government of France. (2011). Cannes Summit Final Declaration. Retrieved from: http://chifl.shufe.edu.cn/upload/htmleditor/ File/111116111741.pdf.

Government of Mexico. (2012). G20 leaders Declaration. Retrieved from: http:// www.consilium.europa.eu/uedocs/cms_Data/ docs/pressdata/en/ec/131069.pdf.

Hallegatte, S., Heal, G., Fay, M., Treguer, D. (2011). From Growth to Green Growth (Policy Research Working Paper, 5872). New York: The World Bank. Retrieved from: http://www-wds. worldbank.org/servlet/WDSContentServer/ WDSP/IB/2011/12/07/000158349_2011120717 1314/Rendered/PDF/WPS5872.pdf.

Heal, G. (2012). Reflections-defining and measuring sustainability. Rev. Environ. Econ. Policy, 6(1), 147-163. doi:10.1093/reep/rer023.

Jacobs, M. (2012). Green Growth: Economic and Political Discourse (Working Paper No. 108; Working Paper No. 92). Centre for Climate Change Economics and Policy; Grantham Research Institute on Climate Change and the Environment. Retrieved from: http://www.Ise.ac.uk/Granthamlnstitute/wpcontent/uploads/2012/10/WP92-green-growtheconomic-theory-political-discourse.pdf.

Jänicke, M. (2011). "Green Growth": From a growing eco-industry to a sustainable economy (FFU-Report 09-2011). Forschungszentrum für Umweltpolitik, FU Berlin. Retrieved from: www.gws-os.com/discussionpapers/gwsresearchreport13-1.pdf.

lanchovichina, E., \& Lundstrom, S. (2009). What is Inclusive Growth? Washington: The World Bank, PRMED. Retrieved from: http:// siteresources.worldbank.org/INTDEBTDEPT/ Resources/468980-1218567884549/ WhatlsInclusiveGrowth20081230.pdf.

KPMG Central and Eastern Europe, Ltd. (2007). EU Funds in Central and Eastern 
Europe Progress Report 2007-2012. Retrieved from: http://www.kpmg.com/LT/ en/IssuesAndInsights/ArticlesPublications/ Documents/EU\%2 OFunds \% 20 in \% 20 Central\%20and\%20Eastern\%20Europe\%20 -\%20Progress\%20report\%202007-2012.pdf.

Mohl, P., \& Hagen, T. (2009). Do EU structural funds promote regional growth? Evidence from various panel data approaches. 15th International Conference on Panel Data. Bonn. Retrieved from: http://www.iza.org/ conference_files/pada2009/mohl_p5182.pdf.

OECD. (2011). Towards Green Growth. Paris: Organisation for Economic Co-operation and Development. Retrieved from: http://www. oecd.org/greengrowth/48012345.pdf.

OECD. (2011). Towards Green Growth: Monitoring Progress - OECD Indicators. Paris: OECD. Retrieved from: www.oecd.org/ greengrowth/48224574.pdf.

OECD. (2012). OECD Work on Green Growth. Paris: OECD http://www.oecd.org/ greengrowth/oecdworkongreengrowth.htm.

Puigcerver-Penalver, M. (2004, April 14). The Impact of Structural Funds Policy on European Regions Growth. A Theoretical and Empirical Approach. Retrieved from: http://fmwww.bc.edu/repec/esLATM04/ up.23143.1081937884.pdf.

Reilly, J. (2012). Green Growth and the Efficient Use of Natural Resources. Energy Economics. 34(Suppl. 1), S85-S93.

Rodriguez-Pose, A., \& Fratesi, U. (2004). Between development and social policies: The impact of European structural funds in Objective 1 regions. Regional Studies, 38(1), 97-113. doi: 10.1080/00343400310001632226.

Samans, R. (2013). Green Growth and the Post-2015 Development Agenda. An Issue paper for the United Nations High-Level Panel of Eminent Persons. Retrieved from: http:// www.greengrowthknowledge.org/sites/default/ files/downloads/resource/GG_and_the_post2015_development_agenda_Gggi.pdf.

Schmalensee, R. (2012). From "Green Growth" to sound policies: An overview. Energy Economics. 34(Supplement 1), 52-56. doi:10.1016/j.eneco.2012.08.041.

Streimikiene, D., \& Balezentiene, L. (2012). Assessment of Electricity Generation
Technologies Based on GHG Emission Reduction Potential and Costs. Transformation in Business and Economics, 11(2A), 333-344.

UN. (2012). Resolution adopted by the General Assembly, The future we want, A/ RES/66/288, 11 September 2012. Retrieved from: http://www.un.org/en/ga/search/view_ doc.asp?symbol=\%20A/RES/66/288.

UNEP. (2011). Towards a Green Economy: Pathways to Sustainable Development and Poverty Eradication. Nairobi: United Nations Environment Programme. Retrieved from: http://www.unep.org/greeneconomy/Portals/88/ documents/ger/GER_synthesis_en.pdf.

UNCSD. (2012). United Nations Conference on Sustainable Development. Retrieved from: http://www.uncsd2012.org/content/ documents/814UNCSD $\% 20$ REPORT $\% 20$ final\%20revs.pdf.

World Bank. (2012a). Inclusive Green Growth: The Pathway to Sustainable Development. Washington, DC: World Bank. Retrieved from https://openknowledge. worldbank.org/handle/10986/6058.

World Bank. (2012b). MDBs: Delivering on the Promise of Sustainable Development. Washington, DC: World Bank. Retrieved from http://www.worldbank.org/en/news/ feature/2012/06/19/mdbs-delivering-promisesustainable-development.

World Bank. (2012c). Green Growth Knowledge Platform. Washington, DC: World Bank. Retrieved from http://www. greengrowthknowledge.org/.

World Commission on Environment and Development. (1987). Our Common Future (The Brundtland Report). Oxford / New York: Oxford University Press. Retrieved from: www. un-documents.net/our-common-future.pdf.

\section{Prof. Dalia Štreimikienè, Ph.D.}

Vilnius University

Kaunas Faculty of Humanities dalia.streimikiene@khf.vu.It

Assoc. Prof. Asta Mikalauskienè, Ph.D. Vilnius University Kaunas Faculty of Humanities asta.mikalauskiene@khf.vu.It 


\title{
Abstract
}

\section{GREEN GROWTH AND USE OF EU STRUCTURAL FUNDS IN BALTIC STATES, CZECH REPUBLIC AND SLOVAKIA}

\author{
Dalia Štreimikienè, Asta Mikalauskienè
}

Green growth is resource-efficient, cleaner economic growth and more resilient growth without slowing it. "Green growth" not only affects the quality of growth, but overall production. In this case, growth results from the investment in the upgrading of the entire production system to environmental and resource-saving processes and products. A prototype of this phenomenon is the climate-friendly "low-carbon economy." Green growth is expected in implementation of Europe 2020 stratgey and can provide to harminized development and cohesion of old and new EU member states. Europe 2020 is the EU's growth stratgey based on the growth of smart, sustainable and inclusive economy.

The comparative study of green growth indicators and use of EU Structural Funds in 2007-2013 period in Baltics and Czech Republic and Slovakia was performed with the aim to define the role of financing from EU Structural Funds for enhancement of green growth in Baltic States, Czech Republic and Slovakia. The performed comparative assessment revealed that Czech Republic allocated the highest share of means form EU Structural Funds to enhance green growth. In terms of development of green growth indicators Czech Republic is also among the best performing countries following Estonia. The analysis of the use of EU Structural Funds in 2007-2013 in five new EU member states indicated that the EU Structural Funds has positively influenced the development of RES in Baltic States, Czech Republic and Slovakia. The increase of renewable energy capacities in Baltic States, Czech Republic and Slovakia also contributed to the reduction of carbon intensity of economy, reduction of environmental pollution, climate change mitigation and energy import dependency.

Key Words: Green growth, EU structural funds, Baltic States, Czech Republic, Slovakia.

JEL Classification: M12, M53.

DOI: 10.15240/tul/001/2016-2-004 